Proceedings of the Seminar on the Social and Economic Effects

of Earthquake Prediction, 12 October, 1977.

\title{
THE ECONOMIC ISSUES
}

\author{
G. Thompson*
}

SUMMARY

\begin{abstract}
Expectations are a major factor in economic behaviour. If we expect prices to rise, we buy now rather than later, increasing the demand for goods and ensuring that their prices will indeed increase. If we expect share prices to fall, and act on that premise, share prices will fall. Expectations of an economic recovery will stimulate investment and speed the recovery. They are, to a degree, self-fulfilling.

This has obvious implications for earthquake prediction. If the prediction is believed, it will have economic consequences. In this paper I suggest that the economic consequences of such a prediction may be as important as the impact of the earthquake itself.
\end{abstract}

\section{THE EARTHQUAKE}

We are talking about a major earthquake in a region containing about 350,000 people at the time of the 1976 census, 11 percent of New Zealand's population. The population has grown more slowly than the national average $(7.9$ percent between the 1971 and 1976 censuses, as compared to a national average of 9.3 percent) mainly because the very slow growth (1.6 percent in 5 years) of the Wellington urban area has offset faster growth in the Hutt Valley, the Porirua Basin and up the coast.

The Wellington region contains about 10 percent of the factories in New Zealand and provides about the same proportion of manufacturing employment and output. There is not much agriculture or mining but the commercial sector (because of the number of head offices), transportation (because of the Port of Wellington) and the public services (obviously) are all important in national terms. It is a "white collar" concentration - 63\% of regional employment was in this category in 1971 as compared to the national average of 48 percent, and the ratio has probably increased since then. Half of this employment is concentrated in the small central business district, an area particularly vulnerable to attack, whether from above or below ground.

The region contributes perhaps 9 or 10 percent of the GNP, estimated at $\$ 14.5$ billion in 1977-78, and could contain slightly more of the total stock of capital - dwellings and commercial and public buildings, plant and machinery, and infrastructure facilities like motorways, tunnels, docks and water, sewer and gas systems. In current values, at an assumed capital-output ratio of $7: 1$, replacing Wellington could cost about $\$ 10$ billion.

Because of its central administrative, defence, financial and commercial functions, a major earthquake in Wellington would have ramifications extending well beyond the

* Economist, Monetary and Economic Council. range of secondary damage the earthquake would cause in neighbouring regions. As an order of magnitude, the temporary disruptions of the Wellington regional economy might cause a 3 percent drop in GNP. That is about the amount of growth in real GNP we secure in an average year.

Neither the Wellington region, nor the rest of New Zealand, has much recent experience of disasters large enough to have a national economic impact - no wars, invasions or occupations, great floods or droughts, or even large earthquakes in the main centres of population. It would nevertheless not be difficult to calculate the effect of earthquakes of varying magnitudes on the Wellington economy - if there was available a detailed study of the region's economic structure. None seems to have been made. This is a serious information gap and one which, for many reasons other than that of earthquakes, ought to be remedied. From the economic standpoint, the really significant earthquakes would be those of intensity 7 or above. We understand from Dr Smith's analysis (Ref. I) that the "approximate return period" for an earthquake of this size in Wellington is 20 years and for a highly destructive magnitude 8 shock, 50 years, and we have taken some precautions.

Without warning, a major earthquake in Wellington would cause damage, distress and a number of deaths The central business district would, presumably, be most affected and this would have national as well as regional consequences. At the same time, a sudden disaster would produce a positive economic, as well as social and personal, response. The traditions of self-help and of community response to others' misfortunes still seems to be alive and well. There is an administrative basis for reasonably rapid, moderately effective response to unforeseen disaster. As in Napier, or Darwin, or wartime Britain, people would be helped, encouraged and assisted by other people, and at least partiy compensated by the authorities for loss of property, employment or income. If the response were European or Japanese, 
the recovery could lead to new growth and prosperity. In the long run, the benefits of destruction might exceed the ccsts.

What if the earthquake were predicted?

\section{THE PREDICTION}

The state of the art is a matter for scientists, but from recent articles by Professor Evison I take it that the possibility exists of predicting earthquakes of magnitude 6 up to 3 years in advance and those of magnitude 7 perhaps 5 to 9 years in advance, once a "precursory swarm" of shocks is identified. If the precursory gap - the interval between the swarm and the main event - does lengthen according to the size of earthquake, this is a very handy phenomenon. The larger the main shock, the more time is needed and could be available for advance economic and social planning.

To exert an economic influence, however, an earthquake prediction would have to be authoritative, fairly specific and probably reasonably close to the event. Economists have a low opinion of predictions. There are so many of them, confronting a science that is notoriously inexact. Most evoke little response from decision-makers, although that does not stop in making them. They are often wrong. We do respond, in variou ways to clear evidence of trends, to specified future events and often also to those with a high probability. Otherwise, we discount all except the immediate future, relying on short-term forecasts (an art very different from medium-term projections) or simply on current observations. We stock up immediately before the price rise, or on Budget night, not a year or 5 years before. We use less power after the cost goes up, not to avoid an increase beforehand.

Underlying the prediction of an earthquake, however, would be a substantial layer of fully scientific analysis with considerable persuasive force. Dr Smith's isoseismal maps show that we have managed to build the capital near the centre of New Zealand's main earthquake zone; that on the basis of data available from 1840 - 1975 the approximate return period for a magnitude 7 shock in Wellington (or Nelson) is 20 years and for a magnitude 8 shock; 50 years, and that the economic adjustment to these uncomfortable facts has to be made at some stage. Any prediction could only encourage precautionary action.

Even so, the long-range prediction of a major Wellington earthquake, say magnitude 7, in 1984 plus or minus 4 years, might interest planners without having any impact on economic behaviour. The progressive refinement of the prediction could, however, produce a economic response. My guess is that a prediction at 3 years' range or less, specifying a large and well-defined magnitude and a fairly high probability of occurrence in a particular half-year, quarter or month, would be needed before significant action (as distinct from forward planning) occurred.

The prediction would have to be authoritative. A prediction that the world will end next Monday is unlikely to have much effect, unless perhaps it emanates from an established church. Not much more notice, I suggest, would be taken of reputable individual scientists who predicted Wellington's next earthquake. The prediction would become respectable only with the imprimatur of the government. An individual government source would be insufficient: a conmittee of experts would be required. Full political endorsement would be necessary - there would be no question of the government predicting an earthquake and the Opposition claiming this to be the result of inefficient, if not dishonest, administration. An authoritive, agreed, official prediction would at some point have to be made. This would be a collective statement, handily absolving any individual responsibility. And its economic consequences would be wide.

\section{THE EFFECTS}

New Zealand is neither a centrally planned nor an open market economy. The economic responses to the prediction would be very different from those in China or the United States. We have far more private enterprise than the former but also much more central government than the latter. In a mixed public-private economy with advanced welfare systems, disasters are largely a state responsibility. They become almost entirely so if it is the government that predicts the disasters.

A recent U.S. article (ref. 3) suggests what might happen if market forces operated here with as much freedom as in California. In this scenario, the U.S. Geological Survey is said to announce in July 1976 that an area including most of the greater Los Angeles basin is being designated as an area of intensive study of possible earthquake precursor data. Two reputable private seismologists say that their analysis convinces them that there is a $25 \%$ chance of a damaging earthquake along a well-known local fault in 1979. Less than a year later, it is found that population growth in the area has slowed; fewer businesses have opened; and much construction has stopped. The formal endorsement comes in August 1977 when the USGS predicts an earthquake in October or September 1979; the expected magnitude is 7.0 or greater; the estimated probability 50 percent. This stimulates much administrative action. The main economic consequence is a more drastic fall in construction activity, though work in progress continues. By December 1977 , 80 percent unemployment exists in the building trades and workers are moving out. Savings and loan associations contract their operations; mortgages are more costly and very difficult to find and property hard to sell. Sales tax revenue begins to decline and public service economies are needed.

In November 1978 the prediction becomes more specific: the date september 1979 (less than 10 months away); the magnitude 7.1 7.4 ; the probability now 80 percent. Business activity declines more rapidly, umemployment escalates. A few national firms move to other locations. Most start losing money. Many small businesses fail by the end of 1978. 25 percent have gone bankrupt or have sold out. Local government income declines, and funds for libraries, parks and rubbish collections have to be 
cut to provide funds for more vital services. Property values drop to the lowest levels in years. The whole regional economy is in recession well before the event. The authors of this scenario note that the most intensive reactions occurred when the probability was increased to 80 percent. In another situation, this might occur $2-3$ years rather than a few months before the predicted earthquake.

I suggest that our individual and market responses would not be so different. once a prediction about wellington became generally accepted, the region would be in latent economic decline.

The reaction of some people would be to sell up and move out. We are a propertyowning democracy: houses and business premises are the largest part of most people's wealth, and are not lightly put at risk. Having discovered that the supply of housing and commercial property had increased, the demand had declined and sales were difficult to secure, most owners might then decide to brave it out. They would want their investment protected. The Government would be asked to give assurances. Those renting or leasing would have more flexibility. Some might leave if their job situations or prospects worsened. The normal outflow of people would continue or increase. The normal inflow would decline. Business activity would start to decline, discouraging new ventures.

The potential effects on investment would be serious. Investment expenditures produce 20 - 25 percent of national or regional incomes. Up to half of the expenditure is on construction, which provides 8-10 percent of output or income, possibly more in wellington region, a hive of public and private construction activity. If this halved or, as in the U.S. scenario, dropped by $80 \%$ the direct employment affects would be very serious. The indirect, multiplier effects of a change in investment spending are also known to be large. Somehow, investment would have to be maintained. This might be even more difficult in New Zealand, where it takes much longer to complete a building or notorway than in most other countries. Uncompleted structures are apparently more vulnerable than finished works. Who would ensure that any project started in wellington would be finished by the time of the earthquake?

Investment, employment and demand effects generated by the prediction would presumably have to be offset by government action. This could be done more easily in the public sector (which accounts for 25 percent of expenditure on a national basis, not counting benefits, and might cover as much as 30 percent in the Wellington region) than in the private sector. Private enterprise would have to be given strong incentives to keep going. In effect, there would have to be a regional development policy with subsidies, tax incentives, and other provisions - designed not for growth but to prevent undue contraction. It would be expensive. Any firm expressing the intention of pulling out would be offered incentives to stay, or another offered larger incentives to replace it. Alternatively, the government could purchase ownership or control. This too would be costly. Unemployment could not be allowed to exceed the national average. Schemes would have to be devised to prevent this.

A further economic effect would be to create (even if the plans to maintain aggregate output, incomes and employment were successful) a static economy, until after the event. Few new initiatives would be financed. The normal process of growth and change would be suspended. Any change would be discouraged. For example, any further decentralisation of public sector activity (like shifting more of the Government Printing Office to Masterton) would have to stop. No other commercial head office could be allowed to move to Auckland. Goods would have to flow north or south, through the port, as usual. "Confidence" would have to be maintained.

There could be positive features during this gestation period, in investment and other fields. In the private sector, short-term, high yield projects might be encouraged - and we need those more than new office blocks. New access or escape roads could be built. If the shelf of projects were available, some sensible and beneficial investments could be made. Much of the activity, however, could be defensive - shoring up existing structures rather than creating new ones.

\section{AFTER THE EVENT}

Once immediate recovery operations were over, Wellington could experience a burst of investment, growth and prosperity based on the popular belief that lightning would not strike again in the same place, at least for 20 years. This would be a highly positive aspect of the prediction plus the preparatory contribution of the Government. Without that contribution, the prospects would be much more bleak in Napier or other earthquake locations, rapid growth has not followed the event, although this was not the result of a prediction. Prior planning would be possible with a prediction. A shelf of projects would be available in both public and private sectors, and they would be implemented. None of this would cost Wellington anything - it would all come from the national purse.

It might be a very different story if the earthquake failed to occur. The uncertainties generated by the prediction could remain for an indefinite period to blight the regional economy. Assistance would taper off. The outflow of people would no longer be discouraged. Perhaps only an earthquake would clear the way for a revival of investment, production and trade.

What about the temptation to postpone a prediction so as to minimise the economic effect? There are at least two deterrents. The longer the advance warning, the more time would be available for planning administrative actions and defensive construction measures. It would be irresponsible not to publish the warning. And if the prediction existed, word might spread well before an announcement was made. This would also have economic 
consequences, including the possibility of speculative gains.

The authors of a prediction seem to have responsibilities extending to the economic as well as social and scientific consequences of their actions. They should know more about them. Much of what has been said here is hypothetical, or speculative, although there are enough parallels in other areas of economics to provide food for thought. Very little work of substance seems to have been done on the economic aspects of earthquake prediction. It should be, both for the Wellington region. an especially vulnerable location, and for New Zealand as a whole.

\section{REFERENCES}

1. W. D. Smith, "Statistical Estimates of the Likelihood of Earthquake Shaking Throughout New Zealand" Bulletin of the N.Z. National Society for Earthquake Engineering, Vol. 9, No. 4, Dec. 1976.

2. F.F. Evison, "Precursory Seismic Sequences in New Zealand" N.Z. Journal of Geology and Geophysics, Vol. 20, No. 1 (1977); and "Fluctuations of Seismicity before Major Earthquakes", Nature, Vol. 266, No. 5044 (April 1977).

3. J. E. Ha.s and D. S. Mileti, "Consequences of Earthquake Prediction on Other Adjustments to Earthquakes" AAS Symposium on Natural Hazards in Australia, Canberra, May 1976.

\section{DISCUSSION}

Discussion concentrated on the effect of the prediction on the economy. Mr. Thompson re-emphasised that a prediction would allow economic planning to preceed the event and should result in a smoother recovery of the economy. 